\title{
Anne Gjelsvik
}

\section{Ethical Readings in the Unbiassed Sphere of Fiction}

\section{English Summary}

This article defends an ethical criticism of fiction film. Drawing on the so-called »ethical turn « in philosophy and literary criticism, as well as perspectives from new tendencies in cognitive film theory, Gjelsvik argues that an ethical criticism is not just possible, but unavoidable.

Using contemporary American fiction film and the depiction of violence as her main case-study, she aims to show that there is no such thing as a separate fictional realm beyond the scope of ethical evaluations. A central example in her discussion is Quentin Tarantino's Kill Bill, a movie which was regarded by the Norwegian film reviewers as a fairy-tale and »just for fun «; accordingly the movie's depiction of violence was not subject to an ethical criticism. Gjelsvik points to several reasons why this position (close to »aestheticism « in art theory) is inadequate, and she proposes a moderate version of ethical criticism instead. She discusses the moderate position as formulated by Berys Gaut and Noël Carroll, both philosophers who also have worked extensively on film art, trying to transfer their perspectives on art onto popular culture.

She argues that such an approach also needs to take into consideration the emotions evoked by the movie and by violent depictions in particular. Whereas cognitive film theorists have foregrounded the similarities between the viewers' emotional response to film and their real-life emotions, Gjelsvik makes a case for the importance of considering the distinctive features of fiction and cinematic depictions.

The overall argument is that, as the relation between moral and aesthetic values is complex, ethical criticism should not aim for categorical evaluation. On the contrary, the position should take into consideration the heterogeneousness of fiction film, for instance in the differences between different movies' depiction of violence, and acknowledge the value of ambivalent reactions towards fiction as well.

\section{Anne Gjelsvik}

Dr.art i filmvitenskap og førsteamanuensis ved Institutt for kunst og medievitenskap, Norges Teknisk Naturvitenskapelige Universitet (NTNU). Hun har vært ansvarlig redaktør i Norsk Medietidsskrift (2002-2006) og blant annet skrevet Vondt \& Vakkert. Vold $i$ audiovisuelle medier, Høgskoleforlaget, 2007 og Fiksjonsfilmens etiske betydninger. Fiksjonsvoldens etiske betydninger - en studie av vurderinger av vold $i$ amerikansk fiksjonsfilm. Trondheim: NTNU 2004. 


\section{Etiske lesninger i fiksjonens frirom}

$\AA ̊ 丿$ utøve en etisk fundert kritikk av fiksjon er en ytterst krevende øvelse. Det er fristende å sammenligne en slik akademisk praksis med linedans, hvor sjansen for å falle ned er rimelig høy, og hvor man dessuten risikerer å falle ned på ulike sider av linen for hver gang. I alle fall har jeg følt det slik når jeg har inntatt en filmteoretisk posisjon som jeg vil kalle »en verdiforankret filmteori.$^{1}$ Årsakene til denne redselen for å falle er flere; noen av dem springer ut av mediespesifikke forhold knyttet til filmmediet, mens andre nok er felles for flere humanistiske disipliner. Som forsker vil man unngå å framstå som uvitenskaplig, subjektiv eller moralistisk, og mange vil derfor definere kvalitetsspørsmål og verdivurderinger som noe som ligger utenfor vitenskapens domene. Wayne C. Booth hevder til og med at mange forskere betrakter etisk kritikk som et oksymoron. ${ }^{2}$ Sammen med andre litteraturforskere som David Parker og Martha Nussbaum har Booth ledet an i det som innenfor litteraturstudiene gjerne blir omtalt som den etiske vendingen. ${ }^{3}$

For filmmediet er den såkalte etiske vendingen ikke ny, få om noen kunstformer har hatt så tette bånd til etiske spørsmål som filmmediet. Debatten om filmens potensielle farlighet er like gammel som mediet selv, og bekymringen har her særlig vært knyttet til framstillingen av sex og vold. I motsetning til andre kunstytringer har filmmediet tradisjonelt vært gjenstand for forhåndssensur, også i de nordiske land hvor prinsippet om frie ytringer ellers har stått sterkt. ${ }^{4}$ De siste par år har jeg, fordi jeg forsker på vold i fiksjonsfilm, for eksempel opplevd stor pågang fra mediene i forbindelse med skolemassakre, som ved Virginia Tech (2007) og i Kahuajoki (2008) og Jokula (2007) i Finland, fordi mediene anser film som en mulig pådriver til drap. Fordi den offentlige diskusjonen om filmmediet har vært preget av en overvurdert frykt for filmens farlighet, og en seiglivet diskurs der sensur av filmmediet har vært ansett som legitimt, har mange medieforskere inntatt en forsvarsposisjon for mediet. Mange, inkludert undertegnede, har ønsket å tone ned tabloide forenklinger om forholdet mellom faktiske voldshendelser og fiksjonsvold, eller å argumen- 
tere for at ytringsfrihetsprinsippet også bør gjelde audiovisuell kunst. ${ }^{5}$

På den andre siden har jeg som filmforsker vært forundret over filmvitenskapens manglende tematiseringer av filmers innhold, betydninger og verdier, og derfor ønsket å diskutere teoretiske innganger til disse temaene innenfor filmvitenskapen. Etter ideologikritikken og feminismens sterke periode på 1970-tallet har filmvitenskapen vært preget av teoretiske posisjoner som nyformalisme, poststrukturalisme og kognitiv filmteori. Den ledende filmforskeren David Bordwells argument for filmforståelse (hvordan film fungerer som film) framfor filmfortolkning (for eksempel av filmens tema og budskap) har i stor grad blitt et gyldig paradigme. ${ }^{6}$ Årsaken til dette er flere, blant annet kan vi se at man innenfor dagens teoretiske paradigme har løftet fram tilskueren som den som konstruerer det semantiske nivået i film. Ved å definere tilskueren som fortolkeren, har filmteoretikeren selv overtatt rollen som en mer distansert observatør. Samtidig, når verdi og betydning forstås som kulturelt relativt og flytende, kommer denne formen for fortolkning i miskreditt. Etter min mening har filmvitenskapen i for stor grad, og i likhet med for eksempel litteraturvitenskapen, overlatt verdivurderinger av filmmediet til debattanter i pressen, filmkritikere og konservative kritikere av film.

Med disse premissene som utgangspunkt har etisk filmvurdering vist seg å være en vanskelig balansegang, som kan illustreres med følgende paradoks. Min avhandling Fiksjonsvoldens etiske betydninger. En studie av forholdet mellom vold i fiksjonsfilm, folelser og vurdering (2004) ble skrevet som et bidrag til den etiske vendingen innenfor filmvitenskapen, med en vekt på å tilføre filmteorien etikkteoretiske perspektiv. Når jeg omarbeidet avhandlingen til læreboken Vondt og vakkert. Vold $i$ audiovisuelle medier (2007) fikk den form av å være et korrektiv til medievitenskapens fokus på forholdet mellom medier og påvirkning, og denne versjonen fikk dermed en sterkere vekt på filmfortolkningens betydning for forståelsen av fiksjonsvold, og mindre vekt på etikkteoretiske perspektiver. ${ }^{7}$ Med andre ord, min usikrede posisjon har blitt å argumentere for etiske vurderinger av fiksjon når jeg henvender meg til mine fagfeller, men mot moralistiske tendenser og for en økt forståelse for film som fortelling, fiksjon og representasjon når jeg henvender meg til offentligheten. I denne artikkelen vi jeg derfor benytte anledningen til å forsøke å kombinere disse to tilsynelatende motstridende posisjonene.

Samtidig som jeg altså vil argumentere for etikkteoretiske perspektiver på filmfortellinger, vil jeg poengtere viktigheten av innsikten i at fiksjonsvold ikke primært er vold, men fiksjon. For eksempel mener jeg at det er fruktbart å skille mellom ulike former for følelser som en fiksjonsfortelling kan skape, som igjen kan ha betydning for hvordan vi vurderer en film. 
Vi kan her skille mellom hva som skjer i fortellingen og hvordan dette er fremstilt av filmskaperen. På den ene siden kan vi ha følelser for hvordan en film er konstruert, for verket, eller for filmen som »film«. Disse følelsene kan være knyttet til opplevelsen av filmatiske virkemidler som kinematografi, redigering, lyd og musikk. En annen kategori følelser er relatert til hendelsene i fortellingen, som voldelige overgrep eller drap, og disse følelsene ligger nærmere de vi har når vi er vitne til virkelige hendelser. Denne kategorien følelser kan omfatte redsel, empati eller ubehag, og kan med den nederlandske filmforskeren Ed Tans begrep betegnes som »fiksjonsfølelser«, det vil si følelser vi har handlingens gang. Disse kan stå i motsetning til det Tan omtaler som "artefaktfølelser", som er direkte knyttet til selve framstillingsformen og til konstruksjonen av filmen som kunstverk, eller med det litt gammelmodige uttrykket »artefakt «. ${ }^{8}$ Mens vi kan nyte framstillingene av en actionscene (for eksempel fargene og bevegelsene) kan vi oppleve ubehag mot det som hender i scenen. Jeg vil vende tilbake til anvendelsen av dette begrepsparet i konkret filmanalysearbeid nedenunder.

Noen flere premisser bør på plass før jeg går over til å diskutere noen mulige etikkteoretiske posisjoner og tematisere noen utfordringer ved hjelp av noen filmeksempler. Hovedfokuset mitt vil hele veien være voldsframstillinger i fiksjonsfilm, både fordi det er det feltet jeg selv har undersøkt mest, både gjennom filmanalyser og i studier av offentlige diskurser omkring vold i mediene, og fordi voldsframstillinger faktisk er et utfordrende og illustrerende case-studie. Jeg tror likevel at en del perspektiver vil være overførbar til andre temaer og andre medier eller kunstuttrykk.

Ovenfor har jeg med hensikt skilt mellom etikk og moralisme. Bakgrunnen for dette er at jeg mener at for mye av det som passerer som etisk kritikk bunner i moralisme. Jeg vil innledningsvis kun anføre en distinksjon fra samfunnsforskeren Alan Wolfe som jeg synes er fruktbar og dekkende for mine egne perspektiv: I følge Wolfe vektlegger en moralistisk posisjon å finne skyld hos andre og inndele »de andre « $\mathrm{i}$ gode og onde. Dette er en posisjon som kan stå i veien for en moralsk holdning, som i større grad handler om å finne det moralske i seg selv, samt å kunne se ting fra »den andres « perspektiv. ${ }^{9}$ Overført til kunstvurderinger betyr det, slik Wayne C. Booth har poengtert, at kritikeren ikke skal vurdere om en moralsk kode er overskredet, men verkets betydninger for tilskuerens ethos. ${ }^{10}$ I denne sammenhengen betyr dette at man ikke skal innta en posisjon der man kun ser på om en film inneholder vold, eller teller opp mengden av voldsinnslag, men heller en mer kontektstualiserende tilnærming, hvor man vurderer funksjonen av virkemidlene i sammenhengen, og hvordan scenene oppleves og forstås av tilskueren. Betydninger må 
dessuten ikke begrenses til måling av effekter og må blant annet inkludere gledene ved å lese, eller å se fiksjon.

Begrepsmessig skiller man dessuten også mellom etikk og moral, hvor moral peker til våre individuelle holdninger og valg, mens etikken forstås som moralens teori, det vil si en mer teoretisk og systematisk framstilling eller behandling av menneskelige sedvaner og handlinger. ${ }^{11}$ I det videre vil jeg derfor beskrive det teoretiske byggverket som etikk eller etikkteori, mens vurderinger av kunstverk kan forstås som for eksempel moralske dommer. Jeg vil også vende tilbake til distinksjonen mellom etikk og moralisme, og hvordan dette også kan nedfelle seg i ulike estetiskteoretiske posisjoner.

Et annet problem i forbindelse med diskusjoner om fiksjonsvold er at posisjonene så ofte er unyanserte, enten forfekter man en posisjon der film er et problem, eller skadelig, eller man hevder at film »bare er fiksjon « eller »uten betydning «. I den offentlige diskursen reduseres fiksjonsvold ofte til størrelser som »fare «, »skadelighet «, »problem « eller »ubehag «. Cineaster vil derimot vektlegge film som estetikk eller form, og den unge tilskuerens forhold til actionfilmen eller skrekkfilmens voldelige framstillinger synes fanget med tittelen på den danske filmforskeren Anne Jerslevs studie av unges videovaner Det er bare film. ${ }^{12}$ Mitt utgangspunkt er at også actionfilmer som for eksempel John Woos Face/Off (1999) og Quentin Tarantinos Kill Bill filmer (2003-2004), eller skrekkfilmserien SAW (2004-2008), reiser etiske spørsmål, men uten å gi oss enkle svar som »vold er skadelig for tilskueren «. I sin drøfting av hvorfor den etiske kritikken har en lav posisjon innen akademia framhever Booth nettopp forenklende kategoriseringer som en av årsakene. ${ }^{13}$ Når den offentlige diskusjonen av etikk er svak, skyldes dette både at dette er en vanskelig disiplin, men også at den seriøse diskusjonen av denne kritikken har manglet, og at teoretiske perspektiv derfor kan gi viktige bidrag. Verdibaserte vurderinger av fiksjonsfilm bør unngå subjektivistiske, forenklede og moralistiske kategoriseringer.

Fiksjonsfilmens betydninger for tilskueren handler ikke om enkle påvirknings-modeller, men om komplekse samspill av filmenes form og innhold i møte med tilskuerens følelser og holdninger. Etikkteoretiske temaer kan belyse noen av disse. Jeg vil i det videre argumentere for at verdivurdering kan være et relevant filmteoretisk felt, til tross for en hittil manglende plass innenfor moderne filmteori. ${ }^{14}$

\section{Etikkteoretiske perspektiver på fiksjon}

En verditeoretisk tilnærming til kunst støter på en rekke dilemmaer og 
utfordringer, og bare noen av disse kan tematiseres her. ${ }^{15}$ Kan kunst i det hele tatt vurderes på et etisk grunnlag, eller må man operere med to atskilte verditeorier, estetikken og etikken? Hvilken betydning har filmenes estetikk for etiske vurderinger? Finnes det rom for følelsesbaserte vurderinger i etikkteori?

Spørsmål om verdi har tradisjonelt vært drøftet innenfor to atskilte verditeoretiske disipliner, nemlig estetikken og etikken. Mens begge disipliner belyser forestillingen om det gode, er estetikken gjerne forstått som læren om det gode eller det skjønne i kunsten, mens etikkens område er det gode eller det rette, fortrinnsvis relatert til det menneskelige liv. Forholdet mellom to ulike verdisett for kunst er utfordrende og har i økende grad vært gjenstand for teoretiske problematisering. ${ }^{16}$ I følge filosofen Berys Gaut er kjernespørsmålet, når det gjelder kunstens forhold til etikk, nettopp forbindelsen mellom etikken og estetikken. Hvordan kan man forholde seg til et verk som er estetisk vakkert, men etisk problematisk? Kan etiske vurderinger være gyldige som estetiske, eller er disse to verdivurderingene atskilte? Er et kunstverks etiske styrker og svakheter også estetiske styrker og svakheter? ${ }^{17}$ Gaut bruker et klassisk og mye anvendt filmeksempel i sin diskusjon av dette spørsmålet, nemlig Leni Rifenstahls nazistiske propagandafilm Triumph des Willens (1935). ${ }^{18}$ Triumph des Willens er allment anerkjent som et stort kunstverk, men er filmens immoralske holdning uavhengig av dens estetiske meritter? Er den ikke tvert imot estetisk feilslått på grunn av sitt moralske budskap? Eller må man se dens moralske ståsted som del av dens estetiske storhet? ${ }^{19}$ Kan man akseptere D. W Griffiths Birth of a Nation (1915) som et filmhistorisk mesterverk, selv om den er rasistisk gjennom sin portrettering av Ku Klux Klan som heltene i fortellingen? Kunstetiske tradisjoner gir ulike svar på slike spørsmål, og det er vanlig å etablere en dikotomi mellom to hovedposisjoner, moralistisk ståsted versus estetisisme (eller autonomisme), eller litt forenklet sagt mellom en posisjon som er for, og en som er i mot en etisk kritikk av kunst. ${ }^{20}$ Som det vil gå fram av det følgende opplever jeg begge disse posisjonene som for kategoriske.

Innenfor en autonom posisjon blir kunsten forstått som et særegent felt som har sin egen funksjon og sine egne standarder for vurdering, vanligvis forstått som estetiske kriterier, enten knyttet til formale aspekt eller den estetiske opplevelsen. En film som den nevnte Face/Off vil slik kunne vurderes ut fra sin vellykkethet som spennende og spektakulær actionfilm, eller gjennom kvaliteten på skuespillerpresentasjoner og kinematografi. Mens filmens åpningsscene med drapet på et lite barn, kampen mellom den onde antagonisten og den gode protagonisten, eller det lange hevnoppgjøret i filmens sluttsekvens ikke blir vesentlig å tematisere. En 
slik posisjon kan knyttes til det såkalte »interesseløse velbehaget « fra Kant, som atskiller kunst fra praktisk, kognitiv eller etisk verdi. ${ }^{21}$ Estetikken forstås innenfor en slik posisjon som et eget område som ikke inkluderer moralske vurderinger, og i lys av dette vil denne posisjonen for eksempel kunne gi plausible teoretiske argument mot sensur. En slik estetisisme har noen ganger sitt uspring i en (relevant) bekymring for at en etisk kritikk vil framstå som reduserende, ved at man for eksempel kun vurderer en films tema eller innhold, og ikke vurderer det genuint filmatiske. Den kan også representere en motvekt til et instrumentalistisk syn på kunstens didaktiske eller etiske effekter. ${ }^{22}$

I sin ytterste konsekvens vil estetisismen kunne representere en holdning der moralsk evaluering av kunst blir vurdert som irrelevant. Selv om noen kunstverk (for eksempel ikke-verbal musikk) tilsynelatende kan være hevet over en etisk kritikk, er det opplagt ikke tilfellet med for eksempel Triumph des Willens, eller vil jeg si Natural Born Killers. Kunstens forbindelse til virkeligheten er særlig åpenbar når det gjelder narrativ fiksjon, og særlig har litteratur derfor vært det foretrukne studieobjektet innenfor den etiske dreiningen innenfor kunstfilosofien. ${ }^{23}$ Selv om det finnes kunstverk som unndrar seg en moralsk vurdering, er det altså innlysende at noen kunstverk eksplisitt behandler ideologiske og moralske temaer, som det ville være absurd å ikke forholde seg til. Et av filmforskeren og filosofen Noël Carrolls opplagte eksempler er her George Orwells roman Animal Farm. Alle de tre eksemplene jeg har nevnt her synliggjør noen opplagte tilfeller hvor moralske vurderinger synes relevante, men etiske diskusjoner er etter min mening enda mer interessant i tilfeller hvor den moralske holdningen ikke er like opplagt som i Animal Farm. Jeg vil hevde at moralsk engasjement er gyldig også i forbindelse med filmer som Matrix (Wachowski 1999), Kill Bill eller Pulp Fiction (Tarantino 1994), til tross for at dette er populærkulturelle produkter med utydelig moralsk budskap.

Med bakgrunn i kognitiv psykologi og filmteori kan vi finne flere grunnleggende innvendinger mot en autonom posisjon. Noël Carroll etterlyser overbevisende argumentasjon for hva som skulle definere et fundamentalt skille mellom estetikkens sfære og den virkelige verdenen, eller hva en fullverdig karakteristikk av det unikt kunstneriske skulle bestå av. ${ }^{24}$ Mot forståelsen av kunsten og verden som atskilte sfærer argumenterer Carroll for at forbindelsen mellom kunst og verden er tilstedeværende i all resepsjon av kunst. For å forstå et litterært kunstverk trekker leseren på sin kunnskap om språk og verbale assosiasjoner, og på sin kunnskap om den »virkelige verdenens « virkelige mennesker og hverdagslig moralsk forståelse. ${ }^{25}$ Carroll argumenterer dessuten for at fiksjon, til tross for at 
den er fiktiv, kan gi oss lærdom og innsikt, for eksempel om hvordan det er å være en karakter i en for oss ukjent situasjon, for eksempel i utfordrende etiske dilemmaer, krigssituasjoner osv. Gode eksempler på dette er for eksempel Clint Eastwoods to filmer fra kampene på Iwo Jima under andre verdenskrig (Flags of Our Fathers og Letters from Iwo Jima 2006), som både går tett på etiske ufordringer under krigshandlinger, men som også ser krigen fra to sider, gjennom å fortelle en amerikansk og en japansk versjon av hendelsene.

Omvendt kan den moralsk funderte kritikken sies å betone forholdet mellom fiksjon og virkelighet i for stor grad, og noen moralske kritikere snakker som om alle vet hvilke handlingsmessige konsekvenser kunst vil gi. I forlengelsen av dette kan vi si at den moralske kritikken heller enn å evaluere enkeltverk kan komme til å vurdere noe annet og utenforliggende enn verket i seg selv. ${ }^{26}$ Dette er i alle fall en gjenkjennelig og relevant problemstilling i forbindelse med medievold, hvor det i diskusjonen om forholdet mellom medievold og virkelig vold er en klar tendens til at man kritiserer filmvold per se. Det man vurderer kan dermed lett bli »filmvold « og ikke den konkrete filmen, for eksempel Oliver Stones Natural Born Killers (1994) eller Mel Gibsons Apocalypto (2006), som begge vekte stor debatt i Norge. Mitt utgangspunkt vil være at forskjellene mellom disse to filmene, for eksempel knyttet til genre, filmatiske virkemidler og karakterframstillinger, er så store at de ikke kan slås sammen i en felles vurdering av moralsk budskap, og at man uansett ikke må la enkeltverkene av syne om en etisk fundert kritikk skal være vesentlig.

Et annet problem ved denne posisjonen er at moralister vil kunne hevde at å fjerne det etisk problematiske i en film vil gjøre den til et bedre kunstverk. ${ }^{27}$ Denne posisjonen vil dermed ofte argumentere for sensur, eller ta avstand fra enkeltscener. Dette var for eksempel tilfelle i forbindelse med norske kritikeres vurdering av Reservoir Dogs (Tarantino 1993) hvor flere norske filmkritikere mente at filmen ville vært bedre med mindre vold, eller om man fjernet en bestemt torturscene. ${ }^{28}$

Innenfor sentrale etikkteoretiske diskusjoner de senere årene har det vært vanlig å skille mellom en moderat og en radikal form for etisk kritikk, hvor blant annet Berys Gaut, Noël Carroll samt den britiske filosofen Matthew Kieran, har argumentert for en mer moderat etisk fundert kritikk. Gaut skiller mellom en etisk kritikk (moderat) og en moralistisk kritikk (radikal). ${ }^{29}$ Innenfor den siste vil moralske kriterier enten være de eneste gyldige (og estetiske kriterier settes til side), eller både estetiske og etiske kriterier har gyldighet men de moralske vektes høyest. ${ }^{30}$ En etisk kritikk, som den Gaut gjør seg til advokat for, vil da framstå som mer moderat fordi den vektlegger pluralitet av verdier, hvorav den moralske 
er en. ${ }^{31}$

Med utgangspunkt i en mer moderat etisk posisjon vil man blant annet kunne argumentere for viktigheten av å diskutere hvert verk for seg (og ikke »filmvold «), for eksempel gjennom å vurdere voldsframstillingen i en gitt film. For eksempel kan vi ikke si at fiktive framstillinger av vold alltid vil være et problem, eller at det aldri kan være problematisk. Gaut sammenligner dette prinsippet med en hvit løgn. Å lyve er i prinsippet en etisk svakhet, men det kan i gitte sammenhenger være den riktige tingen å gjøre. ${ }^{32}$ Overført til filmsammenheng, for eksempel knyttet opp mot sensur, kan man hevde at man ved å fjerne det etisk problematiske kan komme til å fjerne estetisk forbedrende komponenter. Et interessant eksempel er den nevnte Reservoir Dogs hvor man kan argumentere for at torturscenen gjennom sin originalitet og intensitet bidrar til å gjøre filmen annerledes og bedre enn andre gangsterfilmer, samtidig som man kan vurdere den aktuelle scenen som etisk problematisk. ${ }^{33}$

I mine undersøkelser av vurderinger av fiksjonsvold i den norske offentligheten, har jeg til gode å finne noen som hevder at voldsframstillinger aldri bør forekomme, selv kritikere av fiksjonsvold vil finne eksempler der voldsframstillinger er viktige eller nødvendige. For eksempel ble det norske regelverket for aldersgrenser på kino endret i forbindelse med Schindler's List (Spielberg 1993), fordi det ble argumentert med at denne filmen var så viktig at også ungdomsskoleelever burde få se den. Aldersgrensen på 15 år ble dermed endret slik at yngre ungdommer kunne se denne, og andre filmer med samme aldersgrense, i følge med voksne. Poenget i denne sammenhengen er at her ansees akkurat denne filmen, som inneholder flere brutale skildringer, som så verdifull og lærerik at disse scenene kan forsvares, av kunstneriske og didaktiske hensyn. Den samme argumentasjonen kan man finne i forbindelse med krigsfilmer som Saving Private Ryan (Spielberg 1998) eller Letters from Iwo Jima. I noen sammenhenger vil voldsframstillinger være akseptable, men hvor går grensene? Et interessant eksempel er den norske mottakelsen av Mel Gibsons Apocalypto, hvor kritikere og sensurinnstanser var uenige i hvorvidt denne filmen var spekulativ og om den egnet seg for unge, eller om den burde få en voksen aldersgrense (18 år). ${ }^{34}$ Denne filmen reiser en lang rekke problemstillinger i forhold til vold i underholdningssammenheng, for eksempel inneholder filmen en lang sekvens med menneskeofring og halshugging, og dramatisk menneskejakt i den søramerikanske jungelen. Imidlertid var det slaktingen av en tapir og spising av rå dyretestikler som vekte mest anstøt blant norske filmanmeldere. Å framstille jakt og slakting kan neppe betraktes som uetisk. Heller enn umoral, er det her snakk om ubehag, og denne filmen er bare et av mange eksempler på at kritikken 
ofte rettes mot de følelsesmessig ubehagelige scenene. En interessant digresjon her er at filmkritikere som ofte betraktes som skolerte og objektive smaksdommere, ofte anvender følelsesmessige kriterier i vurderinger av filmers kvalitet og verdi.

En av de mest interessante og utfordrende sidene ved Berys Gauts posisjon er nettopp følelsenes betydning for den moralske dommen. Et tradisjonelt etikkteoretisk skille går mellom kognitivisme og emotivisme, og synet på hvorvidt etiske dommer er basert på fornuft (og dermed er sanne eller falske), eller om etiske dommer er basert på følelser og dermed kun uttrykk for enkeltpersoners holdninger. ${ }^{35}$ Som et argument mot en moderat etisk kritikk kan man derfor anføre at etiske innvendinger kun vil være relevante i forbindelse med menneskelige handlinger, men altså ikke for tanker eller ideer, eller fiksjon, som må betraktes som en frisone. Den amerikanske filosofen Ted Cohen beskriver for eksempel hvordan man kan forstå etikken som et felt der man skiller mellom handling og holdning, mens det i estetikken kun vil være tale om følelser og ikke handlinger. ${ }^{36}$ Ut fra en slik vurdering vil de estetiske vurderingenes betydning være hierarkisk lavere enn etiske vurderinger, fordi de heller ikke har noen handlingsmessige konsekvenser. Fra en rent praktisk etikkposisjon vil man vurdere følelser og tanker, som ikke er direkte motiverende for våre handlinger, som irrelevante for vurderingen av menneskelig moral. Tanker, fantasier og ønsker, uansett hvor uanstendige, grusomme eller korrupte de måtte være, er i henhold til denne posisjonen ikke i seg selv umoralske. ${ }^{37}$ Hvis jeg beundrer en karakter som den onde terroristen Castor Troy i Face/Off, eller seriemorderen Hannibal Lector fra Silence of the lambs (Demme 1991) reduserer det ikke min etiske standard, fordi følelser for fiksjon ikke har praktisk relevans. Altså må man kunne hevde at følelser vekket av fiksjon, eller kunst generelt, ikke kan anføres mot en tilskuer, og at kunsten må være å betrakte som en frisone hvor følelsene kan få spille fritt.

Berys Gaut trekker fram eksempler fra dagliglivet for å vise hvordan våre følelser, og ikke bare våre handlinger, faktisk spiller inn når vi vurderer en persons etiske standard. Dine venner skryter ovenfor deg i forbindelse med noe du har oppnådd, men du oppdager at de egentlig er dypt misunnelige og sjalu. Selv om holdningene deres ikke har hatt konsekvenser for handlingene overfor deg, vil ikke det endre ditt syn på dine venner? Omvendt kan venners omsorgsfulle tanker og sympati ha betydning i en vanskelig situasjon selv om vennene ikke er i stand til å sette disse følelsene ut i handlinger som kan hjelpe i situasjonen. Våre venners følelser og tanker om oss har betydning også når de ikke gir seg utslag i handlinger. ${ }^{38}$ Gaut anfører også hvordan mange karakteristikker 
av personers moral hviler på begrep som ufølsom versus vennlig og empatisk. Dette er uttrykk som beskriver følelser og holdninger, men ikke nødvendigvis handlinger. ${ }^{39}$ Gaut argumenterer derfor for det han kaller en affektivt-praktisk etikkposisjon, som inkluderer både handlinger, motivasjoner og følelser.

I dette perspektivet inkluderes derfor også følelser for fiksjon, fordi en tilskuers imaginasjon og reaksjoner på imaginasjonen følgelig spiller en rolle for denne personens etiske karakter. Våre responser på fiksjon inkluderer også affektive reaksjoner, og verdien av et verk hviler ofte på en slik respons, for eksempel at en romans påstand om kjærlighetens betydning har langt høyere estetisk verdi dersom leseren virkelig føler dette. ${ }^{40} \AA$ forstå en tekst handler også om å mobilisere adekvate følelser, for eksempel skam, indignasjon, forakt eller medfølelse. Kunstverkenes etiske verdi kan vurderes ut fra følelsene de gir oss og den intellektuelle kunnskapen og lærdommen de tilfører. Gaut rubriserer dette som en kognitiv-affektiv posisjon.

Innenfor kognitiv filmteori finnes det i dag en rekke teoretikere som vektlegger tilskuerens aktive medskapning i møte med film, og som også inkluderer følelsenes betydning her, og jeg har stor grad latt meg inspirere av teori og filmanalyser innenfor dette filmteoretiske paradigmet. ${ }^{41}$ Jeg vil i det videre utdype min posisjon ved hjelp av en litt nærmere diskusjon av Kill Bill 1.

\section{Volden $i$ et eget univers}

Mens norske filmkritikere på 1990-tallet i stor grad var negative til voldsframstillinger i amerikansk underholdningsfilm, blant annet influert av en offentlig diskurs der bekymringen for konsekvensene av »medievold « var sterk, var mottakelsen av Quentin Tarantinos Kill Bill-filmer preget av en posisjon der film ble forstått som frisatt fra en virkelig verden. Disse to filmene, i motsetning til for eksempel Mel Gibsons samtidige Passion of the Christ (2004), ble plassert i en kategori filmer som ble betraktet som på lek eller som eventyr. I ungdomskanalen NRK P3 het det for eksempel om Kill Bill vol 1 at: »Quentin Tarantinos fjerde film Kill Bill er en deilig, leken og vakker voldsfest som kjæler med øyeeplet ditt, før den kutter det i to! « ${ }^{42}$ Og i Dagbladet skrev Inger Bentzrud om Kill Bill vol 1 at: »Å protestere mot voldsscenene i denne filmen er som å ha innvendinger mot at Askeladden kapper hodet av trollet. Eventyr har sine egne regler, også på film. «43 Kritikerne baserte sin rubrisering av Kill Bill som etisk uproblematisk på en rekke interessante kriterier som vil danne utgangspunkt for min videre diskusjon her. Jeg vil summere disse ved hjelp av stikkord 
som: vakkert, stilistisk, på lek, eventyr, eget univers, uvirkelig og ikke realistisk. Dette viser en rekke interessante paradokser rundt kriterier for vurdering av vold i fiksjon; kan man for eksempel hevde at det filmatiske alltid skaper en egen virkelighet (»bare fiksjon «) med egne standarder eller »egne regler « der for eksempel »vold ikke er vold «? ${ }^{44}$ Eller gjelder dette bare noen former for fiksjoner, for eksempel filmer som danner egne stilistiske univers, men ikke for filmer som søker å gjengi virkelige hendelser i et realistisk formspråk? Den amerikanske filmforskeren Dana Polan beskrev for eksempel Tarantinos tidligere film Pulp Fiction som et selvinnholdende univers, hvor til og med karakterene var konstruert gjennom sitt inntak av populærkultur. ${ }^{45}$ Et av karakteristikaene ved Tarantinos estetikk er hans utstrakte bruk av intertekstuelle referanser, særlig til annen B-film, noe som gir filmene hans et preg av i første rekke å forholde seg til og å omhandle fiksjonsfilm. Pulp Fiction framsto som imaginær og todimensjonal, og bare på lek, og derfor kunne den, som et eventyr, unndra seg alvorlige innvendinger, for eksempel av etisk karakter.

Jeg vil argumentere for at Kill Bills univers, i likhet med Pulp Fiction, til tross for sitt stiliserte og intertekstuelt funderte fiksjonsrom ikke kan forstås som bare på lek, selv om filmene også er på lek. Mange filmatiske iscenesettelser står langt fra den virkelige verden gjennom for eksempel sin skjønnhet eller sin avstand fra fysiske lover. Et godt eksempel er her også Matrix-filmene (Andy \& Larry Wachowski 1999-2003) hvor Neo kan bøye seg unna kulene som skytes mot ham, eller holde et helikopter med sine egne hender. En postmoderne insistering på at filmer som Kill Bill er liv frisatt fra vår verden, er likevel en feilslutning. Forbindelsen mellom fiksjonens verden og vår egen verden er i første rekke psykologisk, slik også litteraturforskeren Kendall Walton har pekt på. ${ }^{46}$ Jeg vil dessuten argumentere for at forbindelsen mellom fiksjon og virkeligheten er tettere når det gjelder moralske prinsipper, enn la oss si fysiske lover. Vi kan gå med på forestillingen om at noen sannheter kun er gyldige i fiksjonens verden, for eksempel at protagonisten i Kill Bill, »The Bride " (Uma Thurman), alene kan drepe hundre mennesker, eller henge i taket ved hjelp av egen kropp og viljestyrke. ${ }^{47}$ Waltons påstand er imidlertid at vi i forbindelse med moralske henseender er mindre villige til å skille fiksjonen fra vår virkelige verden. Vi vurderer fiksjonskarakterer som om de har blod i årene, følelser og moralske valg. ${ }^{48}$ Selv i forbindelse med stereotypiske karakterer som gangsterbossen O-Ren Ishii (Lucy Liu) eller gangsteren Bill (David Carradine) tiltror vi dem følelser, som det lille barnet O-rens følelser for drapet på sine foreldre, eller Bills omsorg for sitt lille barn. Ikke minst finnes det en rekke grep i Kill Bill som forankrer »The Bride« til våre egne erfaringer (graviditet, morsrolle, forholdet til 
far, redsel for overgrep og fornedring, drømmen om eventyret som hvit brud). Vi vurderer med andre ord fiksjonskarakterer også med standarder fra det virkelige livet. Vi konstruerer fiktive verdener nære vår egen. ${ }^{49}$

I tillegg forankres fiksjonen til tilskueren gjennom de følelsene filmen vekker hos henne, som i dette tilfellet gjennom en original hevnerske, estetiserte sverdkamper, eller overraskende fysiske kamper. Når jeg i ulike sammenhenger har argumentert for relevansen av å diskutere volden og kvinneframstillingen i Kill Bill har jeg blitt møtt med sterke reaksjoner fra kvinnelige tilskuere av typen »Skal du ta fra oss heltinnen vår nå «? Kill Bill tematiserer kvinnelig makt og styrke, og er et av få populærkulturelle eksempler på kvinneroller som, slik som i et eventyr eller i fantasien, kan overskride både kroppens og kulturens begrensninger. Innenfor postfeministisk teori, for eksempel representert ved Judith Butler eller Judith Halberstam, vil slike transgressive iscenesettelser av kjønn potensielt kunne fungere frigjørende og positivt. ${ }^{50}$ Filmen tematiserer imidlertid også seksuelle overgrep, hevn, forholdet mellom kvinne, mann og barn med mer, og selv om filmen framstår som en estetisk lek i en populærkulturell frisone viser engasjementet rundt filmen, blant annet knyttet til »The Bride « som heltinne, at også filmens innhold er relevant å tematisere. ${ }^{51}$

Jeg vil argumentere for at Kill Bill har viktige betydninger, blant annet fordi den vekker sterke følelser, enten det er engasjement og entusiasme eller ambivalens og avsky. Slik den britiske kulturteoretikeren Steven Connor også hevder vil det verdifrie eller verditomme feltet alltid ligge innenfor og omkretset av verdier, aldri i en egen sone. ${ }^{52}$ Å hevde at en film som Kill Bill ikke skal vurderes etisk er også en etisk posisjon. Sagt på en annen måte, den etiske dimensjonen kan faktisk ikke unngås. ${ }^{53} \mathrm{At}$ Tarantinos filmer har blitt så sentrale populærkulturelle referanser viser at dette ikke er subjektive ideer fra en auteurs hode, men noe som treffer de såkalte »tegn i tiden «.

Jeg vil derfor avvise påstandene om Kill Bills manglende etiske betydning. Til tross for fortellingen, karakterenes og referansenes underliggjøring, er filmen bærer av en rekke virkelighetseffekter som også skaper nærhet, men ikke minst opplevelser som har etterlatt erfaringsspor i en rekke tilskuere. Slik virket det i alle fall på publikums sjokkerte reaksjoner da jeg så filmen på Trondheim Kino og »The Bride« trakk ut øyet på den allerede enøyde motstandersken sin »Mountain Snake (Daryl Hannah). Samtidig som man lar seg underholde, kan man i ettervurderingens lys også diskutere hvilke verdier som er på spill i denne leken.

Jeg tror at det å ta innover seg den ambivalensen det ligger i å la seg underholdes av kyniske, men vakre voldsicenesettelser og drøfte denne ambivalensen i et etisk perspektiv kan bidra til økt innsikt både i film og 
tilskuer. At vi liker overskridende representasjoner gjør oss ikke automatisk til umoralske vesener, men det betyr heller ikke at disse representasjonene er uten betydning. Et avgjørende ledd i min argumentasjon er forståelsen av fiksjonsfilmens væren, dens funksjoner og betydninger for våre liv. Fiksjoner representerer ikke et eget univers som er distansert fra vår verden, fiksjoner er ikke »bare fiksjon «. Fiksjonsfilmen forbindes til oss gjennom følelser og engasjement. Et særtrekk ved voldsframstillinger er at de genererer sterke opplevelser, og en etikkteori om fiksjonsvold må derfor også være basert på følelsenes betydning. Følelsene representerer dessuten et viktig bindeledd mellom »den fiktive verden « og vår egen.

Samtidig, fordi fiksjonsfilm selvsagt og først og fremst er fiksjon, må vi ikke slippe av øye at dette er iscenesettelser eller representasjoner. Det betyr at en verdibasert filmteori også må inneholde perspektiver på fiksjonen og estetikkens betydninger. Den kognitive filmteorien vektlegger hvordan det å oppleve film og det å forstå en fiksjon ligner våre sansninger og refleksjoner omkring virkelige hendelser. Å føle noe for fiksjon er forunderlig likt våre følelser i andre sammenhenger, men noen forhold er fundamentalt annerledes. De ønskene vi har for fiksjon kan for eksempel skille seg dramatiske fra de vi har i relasjon til virkeligheten, for eksempel hvilke håp vi har for hva som skal hende våre venner. ${ }^{54}$ Dette er helt sentralt for opplevelsen av fiksjonsvold. Når vi ser en film som The Sixth Sense håper vi at det er sant at den lille gutten Cole (Haley Joel Osment) ser spøkelser, fordi det gjør filmen mer spennende, selv om vi ser at det er en tortur for gutten. Vi ville ikke ønske gutten så vondt hvis han var virkelig. Vi ville ikke ønske å se spøkelser med kulehull i hodet eller overskjærte pulsårer, hvis de var virkelige. Jeg hadde en sterk erkjennelse av dette fenomenet i forbindelse med HBO-fjernsynsserien The Wire (2002-2007). I den episoden som jeg synes er seriens aller beste dør en av hovedpersonene, noe jeg opplevde som trist og et savn, men uten denne hendelsen ville ikke fortellingen få sin sterke forløsning. Våre ønsker for fiktive karakterer er derfor også av en annen form enn de vi har for eksempel for våre venner og kjente, dersom vi ønskte at to elskende som vi kjente personlig ikke skulle få hverandre ville vi være onde. Vi ville være onde om vi mente at det var riktig at noen vi kjenner måtte dø. Slike følelser i forhold til fiksjon gjør oss ikke onde.

\section{Filmformens betydninger}

Selv om jeg har latt meg inspirere av en moderat etisk kritikk innenfor nyere filosofi, vil jeg kort poengtere to problemer med denne retningen slik jeg ser det. Det første problemet er en manglende aksept for at det 
kognitivt og affektivt utfordrende også kan ha et etisk potensial. Noël Carroll synes å mene at kunst som forvirrer oss er moralsk problematisk, og han anvender Natural Born Killers som et opplagt eksempel her. ${ }^{55}$ Men er det faktisk riktig at det bare er filmer med en stabil og entydig moralsk holdning som gir moralsk innsikt hos tilskueren? Min påstand er at etiske drøftinger av filmer som er motsetningsfulle og forvirrende er særlig interessante og relevante. Et eksempel fra et annet kulturfelt er her fotografen Morten Traaviks prosjekt »Miss Landmine « ${ }^{56}$ I dette kunstprosjektet deltar unge kvinner fra Angola, som har mistet en fot eller på annen måte blitt skadet av en mine, i en misskonkurranse, som dokumenteres i form av konkurranse, internett og utstillinger. Prosjektet reiser en rekke etiske problemstillinger. Samtidig som missekonkurransen forankrer kvinneverdighet og lykke til vestlige idealer, synliggjør prosjektet også hvordan viktige temaer (som mineofre) usynliggjøres i offentligheten hvilke tabuer samfunnet har. I form av provokasjonen i prosjektet og ambivalensen det har skapt hos meg, har det iverksetat en lang rekke refleksjoner, som framstår som vesentlige for denne tilskueren. Dessuten framstår det etter min vurdering ikke som adekvat å ganske enkelt avvise filmer eller annen kunst på moralsk grunnlag alene fordi verkene er tvetydige.

Støtte for en slik posisjon kan man finne flere steder. Kultursosiologen Zygmunt Bauman er blant de fremste postmoderne tenkerne som argumenterer for behovet for og potensial i en postmoderne etikk.$^{57}$ Bauman fremhever at mennesket ikke kan beskrives verken som essensielt godt eller ondt, men at mennesket er moralsk ambivalent. Troen på det genuint gode er forfeilet, fordi ingen moralske valg er entydige positive, slik for eksempel omsorg kan utarte til dominans, vil alle moralske valg uunngåelige være aporistiske. ${ }^{58}$ Moralske valg er med andre ord fylt av paradokser og selvmotsigelser, og søken etter klarhet leder kun til mer uvisshet. Moralen er i følge Bauman ikke universell, men genuint heterogen og ikke-rasjonell. ${ }^{59}$ Som nevnt over, våre reaksjoner på utfordrende kunst er ofte ambivalens, og ikke en enten eller reaksjon. I forlengelsen av dette vil min konklusjon være at enhver moralsk vurdering også må baseres på filmenes heterogenitet, og derfor ikke kan utledes fra en gitt størrelse, for eksempel »fiksjonsvold «. Muligheten for å etablere en etikkteoretisk basis som kan favne dette mangfoldet uten grundige og individuelle tekstanalyser framstår for meg som en umulighet, og en verdifundert analyse må derfor inkludere perspektiver på filmatisk framstillingsform. For å kunne forklare ambivalente og komplekse tilskuerreaksjoner må vår teori i større grad innbefatte en forståelse av selve framstillingsformen betydning, enn tilfellet er hos for eksempel Noël Carroll og Berys 
Gaut, som jeg så langt støttet meg til. Å gjengi en films synopsis vil aldri tilfredsstillende kunne kreditere den filmatiske verdien. Kvalitet består ofte av en absolutt spesifisitet ved enkeltverket som ligger i filmens særegenheter i framstillingen. ${ }^{60}$ Det er derfor viktig å etablere perspektiv som ivaretar filmen som et hele, eller sagt på en annen måte, etikkteoretiske perspektiv er ikke alene nok.

Et illustrerende eksempel på formens betydning kan være den nevnte framstillingene av terroristen Castor Troy i Face/Off. Flere ganger i løpet av filmen blir tilskueren oppmuntret til å beundrer terroristen, for eksempel i en eksessiv scene på en flyplass hvor han nærmest framstilles som »Liberace of evil", med elegante klær, slow-motion-bevegelser og musikk. På dette tidspunktet vet vi at han har drept en liten gutt, uten å vise noen former for anger. Han har med kaldt blod plassert en bombe som kan drepe hundrevis av mennesker. Likevel kan vi oppleve å beundre karakteren på lerretet. Også i dette tilfellet er følelsene sammensatte og ambivalente, det vi føler er ikke sadistiske følelser der vi håper at bomben går av, men en blanding av motstand, fascinasjon og avsky. Det vi beundrer er selve framstillingsformen, kinematografi, bevegelser, musikk og skuespill. Det vi beundrer er ikke sadisme, men representasjonen av en ond karakter, for eksempel skuespilleren John Travoltas transformasjon i filmen fra »good guy« til »bad guy«. Når vi beundrer Castor Troy er det representasjonen av Castor Troy vi beundrer. ${ }^{61}$

Filmatiske grep som filmskaperne velger, kan også skape motstridende følelser. Litt forenklet kan vi operere med et skille mellom filmens form og innhold. Mens jeg på den ene siden reagerer med overraskelse og skrekk i møte med det nevnte spøkelset i The Sixth Sense, kan jeg samtidig føle beundring for de grepene som her er valgt. Et særlig intenst eksempel på dette finner vi i den spektakulære scenen hvor ringens brorskap skal krysse broen over Khazad Dum i Peter Jacksons filmatisering av The Lord of the Rings - Fellowship of the Ring (2001). Kombinasjonen av Howard Shores grandiose musikk, som veksler mellom styrke, angst og sorg, sammen med nyskapende digitale effekter gir tilskueren estetiske opplevelser_knyttet til hvordan filmen er laget. Opplevelser som er uavhengig av handlingsforløpet i filmen. Likevel kan vi parallelt oppleve bekymring for hobbittene og skjebnebrødrene deres i flukten fra orker og Balrogen, samtidig som fornemmelsen av selv å stå i fare for å falle i skyggenes dyp er påtrengende. Disse to formene for følelser kan tydeliggjøres ved hjelp av det nevnte begrepsparet utviklet av Ed Tan. Han skiller mellom følelser vi har for hendelsene i fiksjonen (»fiksjonsfølelser«) og følelser vi har for filmen som verk eller konstruksjon. Denne kategorien kaller han »artfaktfølelser«. Dette begrepet peker på at filmen kan oppleves som et 
menneskeskapt »artefakt « eller et verk, og at vi kan ha følelser, for eksempel føle beundring, for filmen som film. ${ }^{62}$ Et slikt skille mellom fiksjonen univers og fiksjonens uttrykk kan bidra til å tydeliggjøre hvorfor det er andre regler for fiksjon, for eksempel hvordan vi kan føle beundre for en film samtidig som vi frastøtes av handlinger som utspilles. Reaksjoner på filmens visuelle eller spektakulære element trenger ikke å skape en mer distansert tilskueropplevelse, fordi tilskueren klarer å ha to ulike opplevelser samtidig. ${ }^{63}$

I noen tilfeller vil følelsene vi har for hendelsene i fiksjonen være dominerende, og den klassiske Hollywoodfilmen tjener ofte som kroneksempel på et slikt tilskuerengasjement. En film som er tradisjonelt fortalt, og ikke benytter særpregede virkemidler vil framstå som »ikke-fortalt « og tilskueren blir derfor mest oppmerksom på hva som fortelles, ikke hvordan det fortelles. Likevel vil jeg hevde at »artefaktfølelser « ofte spiller en stor rolle for opplevelsen, enten det er musikken som vekker oppmerksomheten eller en stemning, eller hvordan en skuespiller spiller en rolle. I Guillermo del Toros Pan's Labyrinth (2006) har vi et eksempel på begge deler. Den vakre voggevisen som går som et ledemotiv i filmen, og den fantastiske skuespillerprestasjonen til 12 -årige Ivana Baquero som spiller hovedpersonen Ofelia, døyvet for denne tilskueren opplevelsen av de grusomme hendelsene som utspilte seg i filmens univers lagt til den spanske borgerkrigen. For egen del oppdaget jeg ved andre gangs gjennomsyn hvordan minnene om de vonde scenene var blitt fortrengt til fordel for det vakre og fantasifulle ved filmen, og at det ubehaglige derfor også denne gangen kom brått på.

Et annet og mer utfordrende eksempel er Natural Born Killers, hvor det ekspressive filmspråket vender vår oppmerksomhet nettopp mot hvordan filmen er laget. I filmens åpningsscene kan tilskueren både føle ubehag og sjokk relatert til hendelsene i fiksjonen hvor seriemorderne Mickey og Mallory tilsynelatende umotivert dreper flere ukjente mennesker i en kafe, men samtidig kan vi oppleve behagelig overraskelse og beundring for elementer ved filmens framstillingsformen. De behagelige følelsene knyttes for eksempel til filmatiske elementer som redigeringen eller soundtracket. I tillegg til at tilskueren slik kan oppleve både behag og ubehag i en og samme scene, kan følelsene skille lag gjennom ved at vi kan føle både sympati og antipati med Mallory i løpet av filmens første fem minutter. Vi vil her kunne oppleve at vår sympati svinger mellom for eksempel Mallory og de tilfeldige ofrene i kafeen. I sum skaper disse kontrasterende følelsene en opplevelse som både er empatisk sjokkartet og distanserende, på måter som kan oppleves som etisk problematiske.

På den annen side, nettopp når filmen skaper en smule distanse til 
fiksjonen eller motstand mot hendelsene, for eksempel knyttet til vår egne etiske standarder for vold, kan vi oppleve at vi tar det lille skrittet tilbake, som ikke bare gjør at vi forstår kunsten bedre, men også oss selv. Som Steven Connor hevder er en av grunnene til at etisk kritikk er så vanskelig er at denne formen for kritikk alltid vil inneholde et element av selvrefleksjon. Vi evaluerer ikke bare filmen, eller fiksjonen, vi ser oss selv, og ikke alltid i et positivt lys. ${ }^{64}$ Men kanskje med litt mer selvinnsikt.

Å vurdere hvilke følelser filmer vekker eller hvilke holdninger de formidler er både relevant og viktig, og denne formen for vurderinger blir ikke mindre viktige selv om vi ikke oppnår fastlagte kategorier for godt eller dårlig, eller endelige konklusjoner om det gode og det onde. Flere studier av hva som forstås som »det gode«, eller hvem som er »de onde«, eller av hvilke framstillingsformer som oppleves som mest ufordrende vil imidlertid ubetinget være et gode. Også populære fortellinger, primært fortalt for å glede eller underholde, formidler verdier, som det er forskerens oppgave å fortolke.

\section{Noter}

1 Jeg inntar denne posisjonen i min avhandling Fiksjonsvoldens etiske betydninger. En studie av forholdet mellom vold i fiksjonsfilm, folelser og vurdering. Trondheim 2004. Se også artikkelen »Mot en verdiforankret filmteori«, i Norsk filosofisk tidsskrift, in Vol. 41:1, pp 47-63. Denne nye artikkelen trekker veksler på begge disse tidligere publikasjonene. Særlig knytter midtpartiet av artikkelen seg direkte opp til den sistenevnte artikkelen, men den forrige artikkelen inneholder også en langt grundigere diskusjon av de etikkteoretiske posisjonene jeg presenterer her, samt en mer utviklet kritikk av moderat etisk kritikk. Jeg skiller der også i sterkere grad mellom teoretikerne jeg diskuterer, mens jeg her har vektlagt å diskutere flere filmer mer i detalj.

2 Wayne C. Booth: »Why Ethical Criticism Can Never Be Simple«, in Stephen K. George (ed.): Ethics, Literature, Theory. An Introductory Reader, Oxford 2005.

3 Se Wayne C. Booth: The Company We Keep. An Ethics of Fiction, Berkeley 1988, Martha Nussbaum: Love's Knowledge. Essays on Philosophy and Literature, Oxford 1990, David Parker: Ethics, Theory and the Novel. New York and Melbourne 1994. For en grei introduksjon til feltet se Stephen K. George: Ethics, Literature, Theory. An Introductory Reader, Lanham \& Oxford, 2005. Jeg har selv hatt særlig glede av Jerrold Levinson (ed.): Aesthetics and Ethics. Essays at the Intersection, Cambridge 1998.

4 I Norge har vi hatt sensur av film fra og med kinoloven av 1913, og først i 2004 ble forhåndssensur av filmer for voksne (over 15 år) opphevet. Se for eksempel http://www.filmtilsynet.no/Nyheter/1096380284.

5 I Danmark er filmforskerne Anne Jerslev og Rikke Schubart eksempeler på forskere som har forsvart voldsuttrykk i film.

6 David Bordwell: Making Meaning. Inference and Rhetoric in the Interpretation 
of Cinema, Cambridge 1989.

7 Avhandlingen tok utgangspunkt i norske filmkritikeres mottakelse av tolv amerikanske fiksjonsfilmer fra 1990-tallet som innholder eksplisitte voldsframstillinger. Med utgangspunkt i den etiske kritikken framført i norsk dagspresse foretar jeg i avhandlingen etikkteoretiske drøftinger, diskusjoner av forholdet mellom følelser og filmfortolkning, samt nærlesninger av flere av filmene i lys av disse premissene. Den bearbeidede versjonen av avhandlingen, Vondt og vakkert. Vold $i$ audiovisuelle medier, Oslo 2007, inneholder dessuten flere nyere filmeksempler.

8 Ed Tan: Emotion and the structure of Narrative Film, Mahwah, N.J, 1996, pp.81-83, og Ed Tan \& Nico Friidja: »Sentiment in Film Viewing «, in Carl Plantinga og Greg Smith (eds): Passionate views: film, cognition and emotion, Baltimore 1999, pp 51-52

9 I debattprogrammet »Beyond the politics «, CNN 05.10.2008 ble Alan Wolfe spurt om USA var et moralsk land og svarte følgende: »We are a moralistic country. We are not a moral country. And there's a big difference between them. Morality involves -- well, in a Christian sense, it involves there but for the grace of God do I, from a moral philosophy standpoint, it involves being able to see things through the perspective of another person. I think we're having moralistic and that actually prevents us from being moral. We want to blame other people rather than look into ourselves. We want to see others divided in the good and evil which really prohibits you from thinking a moral point of view«. http://transcripts.cnn.com/TRANSCRIPTS/0810/05/se.01.html

10 Booth: »Why Ethical Criticism Can Never Be Simple«, p.25.

11 En utfordring for min framstilling her er at de engelskspråklige forfatterne som jeg trekker veksler på anvender begrepene ulikt. For eksempel beskriver Berys Gaut sin posisjon, som »ethicism« og Noël Carroll sin, etter min vurdering beslektede posisjon som »moderate moralism«. Jeg vurderer altså moralisme som noe annet enn en moderat etikkfundert posisjon, og begges posisjoner som en moderat moralsk posisjon.

12 Anne Jerslev: Det er bare film, København 1999.

13 Booth: The Company We Keep: An Ethics of Fiction, p.19.

14 Se for eksempel Noël Carroll: »Introducing film evaluation «, in Christine Gledhill and Linda Williams (eds.): Reinventing Film Studies, London 2000.

15 Jeg betrakter med andre ord film som en kunstform, men er dessuten interessert i anvendelsen av kunstteori også på populærkulturelle fenomen.

16 Se for eksempel Jerrold Levinson: Aesthetics and Ethics. Essays at the Intersection, Berys Gaut: »Art and ethics", in Berys Gaut \& Dominic Lopes (eds.) The Routledge Companion to Aesthetics, London \& New York 2003, eller Robert Eagleston Ethical Criticism, Edinburgh 1997.

17 »Are the ethical flaws (or merits) of work of art also aesthetic flaws (or merits in them)? ", Gaut »Art and ethics«, p. 342.

18 Se også Jeffrey Dean: »Aesthetics end Ethics: The State of the Art«, http:// www.aesthetics-online.org/articles/index.php?articles_id=15, 2002 (sist besøkt 10.11.2008), Mary Devereaux: »Beauty and evil: The case of Leni Riefensthal's Triumph of the will", in Jerrold Levinson (ed.): Aesthetics and Ethics. Essays at the Intersection. Cambridge 1998, Kendall Walton: "Morals in fiction and fictional morality«, in Alex Neill and Aaron Ridley (eds.) Arguing 
about Art, London: 1995 (2002) for diskusjon av samme eksempel.

19 Gaut »Art and ethics«, p. 342.

20 Noël Carroll: »Art and Ethical Criticism: an Overview of Recent Directions of Research «, in Ethics, Vol. 110, no. 2 (Jan 2000) pp.350-387. Gaut mener imidlertid at det finnes tre plausible svar på kunstestetikkens kjernespørsmål, henholdsvis autonomisme (estetisisme), immoralisme og moralisme. Gaut »Art and ethics«. Jeg foretrekker altså begrepet moralsk ståsted i stedet for moralisme, se også note 11.

21 Carroll op.cit, samt Noël Carroll »Art, narrative, and moral understanding «, in Jerrold Levinson (ed.): Aesthetics and Ethics. Essays at the Intersection. Cambridge 1998, p. 134.

22 Jeffrey Dean: "Aesthetics end Ethics: The State of the Art«.

23 Se for eksempel Gaut op.cit og Matthew Kieran: »In defence of the ethical evaluation of narrative art", in British Journal of Aesthetics, Vol 41, No 1, January 2001.

24 Carroll: »Art, narrative, and moral understanding « og Carroll: »Art and Ethical Criticism: an Overview of Recent Directions of Research «.

25 Carroll: »Art, narrative, and moral understanding«. Denne argumentasjonen er fundamentalt kognitiv, og kan finnes igjen hos kognitive teoretikere som David Bordwell og Paul Messari.

26 Carroll: »Art and Ethical Criticism: an Overview of Recent Directions of Research«, p.355

27 Gaut: »Art and ethics«, p.346.

28 Gjelsvik: Fiksjonsvoldens etiske betydninger. En studie av forholdet mellom vold i fiksjonsfilm, folelser og vurdering.

29 Berys Gaut: »The ethical criticism of art «, in Jerrold Levinson (ed.): Aesthetics and Ethics. Essays at the Intersection. Cambridge 1998, pp.182-199. Se ogsa note over, jeg ville her foretrukket begrepet radikal moralsk kritikk.

30 Oliver Conolly: »Ethicism and moderate moralism», in British Journal of Aesthetics, Vol. 40, No. 1, July 2000, pp. 302-303.

31 Gaut op.cit, Connolly op.cit.

32 Gaut: »Art and ethics«, p.347.

33 Jeg skylder å gjøre oppmerksom på at Gaut trolig ikke ville verdsette eksemplet, selv om jeg følger en rekke av Gauts argumenter skiller vi lag i de konkrete vurderingene av filmer som jeg har sett hos ham.

34 Se Gjelsvik: Vondt og vakkert. Vold $i$ audiovisuelle medier, for en grundig gjennomgang av mottakelsen av denne filmen.

35 Se for eksempel Poul Lübcke (red.): Filosofileksikon, København 1996, eller Kjell Eyvind Johansen og Arne Johan Vetlesen Innføring $i$ etikk, Oslo 2000.

36 Ted Cohen: »On Consistency in one's personal aesthetics», in Jerrold Levinson (ed.): Aesthetics and Ethics. Essays at the Intersection. Cambridge 1998, p. 118.

37 Gaut: »The ethical criticism of art «, p.186.

38 Her kan man selvsagt innrømme at dette forutsetter en handling, nemlig at noen forteller om dette, men ikke nødvendigvis, tanken på at noen tenker på en kan være nok.

39 Op.cit, p.186.

40 Op.cit, pp.194-196. Her går Gaut lenger enn Carroll i å forutsette sin etiske modell i kognitiv teori, og han framhever kunstens mulighet for ny kunnen 
sterkere enn Carroll. Jeg har altså valgt å ikke legge vekten på forskjellene mellom Gauts og Carrolls teorier. Fagfilosofer har etablert en diskusjon om posisjonene som sådan og forskjellene dem imellom. Se for eksempel Conolly: »Ethicism and moderate moralism ", Kiran: »In defence of the ethical evaluation of narrative art, og ikke minst Amy Mullin: »Evaluating Art: Morally Significant Imaging Versus Soundness", in The Journal of Aesthetics and Art Criticsm 60:2, Spring 2002. I min sammenheng framstår denne diskusjonen som underordnet, men noen forskjeller bør nevnes. Mens Gaut hevder at alle etiske defekter ved et kunstverk også er estetiske defekter, er Carrolls posisjon at noen etiske defekter også er estetiske defekter.

41 Dette gjelder særlig teoretikerne Murray Smith, Cynthia Freeland, og Carl Plantinga. Se for eksempel Carl Plantinga og Greg Smith (eds): Passionate views: Film, Cognition and Emotion, Baltimore 1999, og Murray Smith: Engaging Characters: Fiction, Emotion, and the Cinema, Oxford 1995.

42 Birger Vestmo: »Kill Bill Volume 1 «, in NRK P3, 23.10.2003, http://www. nrk.no/nyheter/kultur/3196855.html_(hentet 21.11.2004).

43 Inger Bentzrud: »Virtuos dødsdans«, in Dagbladet 23.102.2003, http://www. dagbladet.no/kultur/2003/10/23/381631.html (hentet 23.11.2004).

44 Uttrykket når »Vold ikke er vold « har jeg fra den norske filmanmelderen Jon Selås, som brukte det for i sin argumentasjon for hvorfor han kunne akseptere volden i Pulp Fiction, til tross for at han kort tid før hadde avvist Natural Born Killers på grunn av volden.

45 Dana Polan: Pulp Fiction, London 2000.

46 Kendall Walton: Mimesis as Make Believe, Cambridge \& London 1990, pp.191-192.

47 »It is fictional that it is true «, »Det er fiksjon at det er sant «, Walton op.cit.

48 Walton er her helt på linje med Murray Smith i Engaging Characters.

49 Kendall Walton: »Morals in fiction and fictional morality «, pp.:345-346.

50 Se for eksempel Wencke Mühleisen: Kjønn i Uorden, Oslo, 2002 for gode diskusjoner av dette.

51 Et relevant dansk eksempel er her Lars von Triers Breaking the Waves, som vekte stort debatt og engasjement, ikke minst i dansk presse, og hvor de etiske problemstillingene var knyttet til kvinneframstillingen.

52 Steven Connor: Theory and Cultural Value, Oxford \& Cambridge1992, p. 9.

53 Se også Marshall Gregory, Abraham B. Yehoshua og David Perker in Stephen K. George Ethics, Literature, Theory. An Introductory Reader, for lignende argument.

54 Se også Gregory Currie: »Narrative Desire«, in Carl Plantinga og Greg Smith: (eds.): Passionate views: film, cognition and emotion, Baltimore 1999, for flere perspektiv på dette.

55 Carroll: »Art, narrative, and moral understanding «, p. 150.

56 http://www.miss-landmine.org/

57 Se særlig Zygmunt Bauman: Postmodern Ethics, Oxford 1993.

58 Bauman op.cit, pp. 8-14. Aporia, en motsetning som ikke kan overkommes eller løses. Uttrykket som er hentet fra Platons dialoger blir også anvendt innenfor dekonstruksjonskritikken som »det blinde punkt «.

59 Bauman op.cit, p.11. »They (moral phenomena) are not regular, repetitive, monotonous and predictable in a way that would allow them to be repre- 
sented as rule-guided «. Parantesen er mitt innskudd fra setningen før.

60 Se også Cohen: »On Consistency in one's Personal Aesthetics», en liknende argumentasjon

61 Murray Smith argumenterer også for at tilskuerne som oftes vil reagere med avsky eller ambivalens på de onde karakterenes gjerninger, og rent unntaksvis beundre noen fordi de er onde, se Murray Smith: »Gangsters, Cannibals, Aesthetes, or Apparently Perverse Allegiances «, in Carl Plantinga og Greg Smith: (eds) Passionate Views: Film, Cognition and Emotion, Baltimore 1999.

62 Ed Tan: Emotion and the Structure of Narrative Film og Ed Tan \& Nico Friidja: »Sentiment in Film Viewing «.

63 Dette perspektivet er beslektet med Cynthia Freelands begrep om metafølelser som er et bidrag til å forklare blandede estetiske følelser, for eksempel hvordan vi kan like eller nyte å se horrorfilm. Freeland legger vekt på at en og samme film nettopp kan skape en rekke ulike responser, og at disse responsene kan bestå av blandede eller motstridende følelser. Cynthia Freeland: »Mixed Asthetic Emotions", hand out at »Ethics and Negative Aesthetics «- seminar, Trondheim 21-24.10.2003.

64 Connor: Theory and Cultural Value, p 18. 